Journal of Research in Economics • İktisat Araştırmaları Dergisi • Cilt: 5 / Issue • Sayı: I March • Mart 202I • ss/pp. 99 -I I6

ISSN: 2636-8307 • DOI: 10.29228/JORE.5

ARAŞTIRMA MAKALESI / RESEARCH ARTICLE

\title{
COMPARATIVE ANALYSIS OF PRODUCTION EFFICIENCY IN WEST AFRICA
}

\author{
BATI AFRİKA’DA ÜRETIMM VERIMLILİĞININN KARŞILAŞTIRMALI \\ ANALIZI
}

\author{
Alexandrov N. S. SEMANOU* \\ Kamil USLU ${ }^{* *}$ (6)
}

\begin{abstract}
The status of West Africa as one of the least developed regions in the world eases the multiplication of studies on development in the area. However, despite their high number, these studies are more about macroeconomics policies and show little interest in the quality of the production process itself. This paper makes a comparative analysis of West African countries' efficiency with a focus on four neighbouring countries. These are Benin, Ghana, Ivory Coast and Togo. The study is motivated by the need for going beyond the widely used growth accounting models and performing a comparative analysis between countries using another approach: The Stochastic Frontier Analysis. We find that technical efficiency is relatively high in the zone and varies from a country to another and over time. Ivory Coast turned out to be among the most efficient countries in the production process in the region. Incorporating human capital to the labour factor has different effects on efficiency according to the countries considered. Besides, the comparative analysis sheds light on the differences between the selected countries in both returns to scales and factors' contribution to output.
\end{abstract}

Keywords: Stochastic Frontier Analysis (SFA), West Africa, Growth Accounting, Economic Growth, Technical Efficiency, Comparative Analysis.

JEL Classification: C3, N17, O1, O47, O57, P52

Öz

Batı Afrika ülkeleri dünyanın en az gelişmiş bölgelerinden birisidir. Bölgenin ekonomik kalkınma çalışmalarının çoğalması, bu bölgelerde yaşayan insanların sosyal ve ekonomik refahına katkı sağlayabilecektir. Bölge ülkelerinde, kalkınma çalışmalarının yüksek olmasına rağmen, çalışmalar daha çok makroekonomik politikalarla ilgilidir. Ancak, yapılan çalışmalarda, üretim sürecinin teknolojik kalitesine çok az değinmektedir. Bu makale, Batı Afrika’da dört komşu ülke olan; Benin, Gana, Fildişi Sahili ve Togo’dur ile sınırlıdır ve bu ülkelerin, ekonomik verimliliklerinin karşılaştırmalı bir analizleri yapılmaktadır. Çalışmada, yaygın olarak kullanılan büyüme modellerinin ötesine geçerek, farklı bir yaklaşım "Stokastik Sınır Analizi” kullanarak, adı geçen ülkelerarasında karşılaştırmalı bir analiz elde etme ihtiyacından doğmuştur. Bu bölgede teknik verimliliğin nispeten yüksek olduğu, ayrıca, bir

* Marmara University, E-mail: alexandrov.semanou@gmail.com, Orcid: 0000-0001-9211-3448

** Doğuş University, Department of Economics, E-mail: kuslu@dogus.edu.tr, Orcid: 0000-0002-4518-3133 
ülkeden diğerine ve zaman içinde değiştiğini görüyoruz. Fildişi Sahili, bölgedeki üretim sürecinde en verimli ülkelerinden birisidir. Beşeri sermayenin işgücü faktörüne dâhil edilmesi, ele alınan ülkelerin verimlilikleri üzerinde farklı etkilere sahip olabilmektedir. Ayrıca, karşılaştırmalı analiz, hem ölçeğe göre getiri, hem de faktörlerin çıktıya katkısı açısından seçilen ülkeler arasındaki farklılıklara da ışık tutmaktadir.

Anahtar Kelimeler: Stokastik Sınır Analizi (SFA), Batı Afrika, Büyüme Muhasebesi, Ekonomik Büyüme, Teknik Etkinlik, Karşılaştırmalı Analiz

Jel Sınıflandırması: C3, N17, O1, O47, O57, P52

\section{Introduction}

Several studies in economics focus on measuring the effects of technological change, changes in inputs, and inefficiencies in the production processes. These studies, which have long been devoted to firm-level analyses revealed to be one of the best methods for growth accounting and are very useful for growth accounting studies at the macroeconomic level. Such an analysis takes into account the imperfections of the production processes. Some of these studies emphasize the place of productivity, technical inefficiency, and technological change in the economic (counter-) performances of the countries. Mastromarco (2005) shows that a large proportion of sub-Saharan African countries have high rates of inefficiency in their production processes. Also, the study, that uses data from 1965 to 1990, reveals the existence of decreasing returns to scale and greater labour elasticity in these countries.

In the same line, the present study is interested in another way of doing growth accounting in a region that mostly includes low-income and lower-middle-income countries: The West African region. Indeed, despite the assets and disadvantages (in terms of institution, geography, culture and others) common to the countries, among them, some seem to be much better placed than others in terms the evolution of production over time (see Semanou and Uslu, 2019, p.3). Therefore, it seems important to look at pure economic factors such as capital, labour and, if possible, human capital, behind countries economic performance in this area. Our study aims at conducting a comparative analysis of technical efficiency in West African countries. It is, more specifically, a question of measuring and comparing the level of efficiency and the contribution of each factor of production to the production process in the countries of the region. We, particularly, focus our analysis on countries such as Benin, Ivory Coast, Ghana and Togo. Also, this study provides an analysis of the levels of technical inefficiency and the role of technological change.

To achieve these goals, we use a frontier model of stochastic production with non-neutral technical change. This method has several advantages for growth accounting. It allows seeing the contributions of changes in inputs, technology, and changes in technical efficiency (Mastromarco, 2008). This method, by allowing determining the efficiency levels, the elasticities, and return to scales, facilitates the comparison between firms or countries. The econometric model covers a period of 20 years and involves 12 West African countries. However, we focus our analysis on the four previously mentioned countries. 
Several economic studies conducted in the West African area are on growth. However, this study stands out from the previous ones, essentially, on two aspects. On one hand, the methodological aspect. Indeed, it uses the stochastic frontier method, which, to our knowledge, has not been used yet in economic growth studies in the countries concerned by this study. Secondly, our analysis involves a comparative aspect, on countries (notably Benin, Ivory Coast, Ghana and Togo) which share many similarities, to eliminate the influence of certain non-economic factors. These noneconomic factors could have important influences on growth in countries. Stochastic Frontier model permits to have a better view of the sources of growth in the region by giving the possibility to go beyond results given by a simple regression (Koop et al, 2000b, p.296). Those are, together with the comparative aspect, some of the innovations of this study.

In the next section (Section 2), we present a brief review of the literature relative to our topic. Section 3 is about the methodological approach used in this study. Sections 4 consists of the discussions of the results while Section 5 presents the conclusion.

\section{Literature Review}

Understanding the factors behind economic growth is among the oldest subjects in economics. Growth accounting analyses have generally consisted of analysing the effects of different macroeconomic aggregates on production and most of the studies use traditional growth equation ("à la Barro" for example). However, growth analysis is also about understanding the production process. There are many ways to measure how good this process is. Measuring total productivity, as efficiency measurement, is one way. Both involve a combination of the level of inputs and the level of outputs in their computation. But, despite how close these two terminologies may look; they don't have the same meaning. A firm can be technically efficient but still have the possibility of increasing its productivity (Coelli, et al. 2005, p.4).

Generally used in firm production analysis, the concept of efficiency has been applying to countries (see among others Koop et al., 1999, Koop et al., 2000a, Koop et al., 2000b, Mastromarco, 2005). In the economic literature, there are two sorts of efficiency concept: technical efficiency and allocative efficiency. A firm or a country is (said) technically inefficient when it fails to produce the maximum level of output for a given level of input or it fails to produce a given level of output with the minimum level of input (Mastromarco, 2008, p.10). On the other hand, "allocative efficiency in input selection involves selecting that mix of inputs that produces a given quantity of output at minimum cost" (Coelli, et al. 2005, p.5). Put together, these two concepts give a measure of economic efficiency. There are two main approaches to measure efficiency: the determinist approach and the stochastic approach. The determinist approach attributes the difference between maximum production and effective production to inefficiency, while the stochastic approach allows the possibility of external shocks causing the gap between the maximum production and the realized one (Mastromarco, 2005, p.29). Generally, two estimation methods are used in efficiency analyses. The Data Envelop Analysis (DEA) that is the main 
non-parametric approach (Kotsemir, 2013), and the Stochastic Frontier Analysis (SFA) which is the parametric approach. Mastromarco (2008, p.2) mentions a list of advantages that make frontier analysis one of the widely used methods for growth accounting. According to her, this method provides means to capture "change in inputs use, change in technology and efficiencies". Thus, change in efficiency is considered as one of the sources of gain (respectively) loss in productivity in firms. It also allows comparison between firms or countries

Many studies aiming to analyse technical efficiency use whether DEA or SFA method. These methods are widely used both at firms and countries levels. Even though, in many studies, crosssectional data are used, using panel data seems to give results that are more accurate and more possibilities. Schmidt \& Sickles (1984) identify three problems, which could be avoided using panel data in production frontier analysis. These are:

(1) The non-consistency of estimated firm's technical efficiency factors,

(2) Problems relative to the assumption on the distribution of estimated efficiency and the error terms,

(3) The problem of independence between technical efficiency and inputs.

Also, it allows estimating the individuals' efficiency levels with more precision (Mastromarco, 2008, p.27). Using panel data for production frontier analysis offers many alternatives, in terms of model choice (Karagiannis \& Tzouvelekas, 2009, p.74). Battese \& Coelli (1992) use panel data specification in frontier analysis to measure efficiency in agricultural production in India. Their paper, in the addiction to using panel analysis, has the particularity of using time-variant efficiency factor. They conclude that farmers' inefficiency is decreasing over time and that they were producing at constant returns to scale. Battese \& Coelli (1995), study again Indian farmers, but this time by trying to explain producers' time changing inefficiencies by their characteristics. They conclude that variable such as farmer's age, education level, and the number of years of experience are important in understanding their efficiency. Piesse \& Thirtle (2000), using a translog specification of the stochastic frontier, analyse efficiency in agricultural and manufacturing sectors in Hungary. Their study shows that technology regress has been the cause of change in efficiency and productivity over the covered 7 years. Karagiannis \& Tzouvelekas (2009), make a comparative analysis using different efficiency models and conclude that even though there is no rule for choosing a model or another, one should be careful when doing it.

As previously highlighted, the frontier analysis offers possibilities for growth accounting and allows comparative studies between countries. Koop et al. (1999), using Bayesian estimators of the stochastic frontier model, study the sources of growth in 17 OECD countries. In light of the results, we can say that the situation is different across countries. So, while inputs change is the main contributor to growth in some countries, in others, technical change while in some others, efficiency change of two of the factors or even all the three factors (in the case of Japan, for example) play main roles. Koop et al. (2000a) use a methodology similar to Koop \& al's (1999) 
one, to compare Poland, Yugoslavia, and Western countries' production efficiency over 10 years. The result shows that Yugoslavia is among countries that are more efficient over the period while Poland has a particularly low efficiency level and is the most inefficient among the counties involved in the study. According to the results, over the considered period, efficiency plays little role in the change in income level. Rather, in almost all countries, technical change and inputs change was the main factors with different contributions across countries. Limam (2002) uses the Cobb-Douglas specification of the stochastic frontier model to perform growth accounting across countries. He finds that time-variant technical efficiency hypothesis is true for African, Latin American and South Asian countries but not for Western and Eastern Asia. Also, among the studied regions, Africa is less efficient and has also the highest contribution of labour to growth. Mastromarco (2005) does a similar study on 57 developing countries between 1960 and 1990. But, contrary to Limman, she uses a translog specification of the production function and includes an explanatory variable for efficiency. Kumbhakar \& Wang (2005) use both translog and Cobb-Douglas specifications of stochastic frontier analyses to measure efficiency change, convergence and productivity factors in 82 countries. First, the study reveals the presence of heterogeneity between countries. It also predicts improvement in countries' technical regress and their tendency to convergence toward the frontier. Their study also shows a decreasing in Total Factor Productivity (TFP). However, when inputs are held constant, most of the models show positive TFP growth.

\section{Methodological Approach}

We use a Stochastic Frontier Analysis (SFA), to analyse countries' efficiency. Mastromarco (2005) inspires the model used in our analysis. SFA allows producing estimate and provides a straightforward basis for inferences (Horrace \& Schmidt, 1996). The stochastic frontier model estimated using panel data allows separating technical inefficiency from individual-specific effects, which are not related to technical inefficiency (Mastromarco, 2008). Also, the choice of panel data approach in this analysis comes from the fact that, compared to cross-sections analysis, it helps to go beyond some of its main limitations by providing more information. Thus, with panel data, individual efficiency time path can be estimated, while cross-sectional analysis allows only to measure efficiency in a specific period.

The stochastic frontier function can be obtained by using a frontier production function as followed:

$$
y_{i}=f\left(x_{i} ; \beta\right) T E_{i}
$$

With $y_{i}$ the output of producer $i(i=1,2, \ldots . N), x_{i}$ a vector of inputs, $f\left(x_{i} ; \beta\right)$ is the production frontier, and $\beta$ is a vector of technological parameters to estimate. We can present the technical efficiency of the producer $i$ (expressed as a ratio of the effective output and the maximum feasible output) as follow: 
$T E_{i}=\frac{y_{i}}{f\left(x_{i} ; \beta\right)}$

$T E_{i}=1$ implies that the producer $i$ reach a level of output $y_{i}$ which is the maximum feasible of $f\left(x_{i} ; \beta\right)$ while $T E_{i}<1$ measure the case where output is below its maximum feasible. But all these assumptions are true in the case of deterministic production frontier. We can introduce the effect of external random shocks in the equation using the assumption of the entire gap between $y_{i}$ and the maximum feasible output being not attributed to technical inefficiency. We can then write our stochastic production frontier function as following:

$$
y_{i}=f\left(x_{i} ; \beta\right) \exp \left(v_{i}\right) T E_{i}
$$

Here $f\left(x_{i} ; \beta\right) \exp \left(v_{i}\right)$ represent the stochastic frontier and $\exp \left(v_{i}\right)$ captures the effect of random shocks specific to each producer. We can then rewrite the technical efficiency of the producer $i$ as:

$T E_{i}=\frac{y_{i}}{f\left(x_{i} ; \beta\right) \exp \left(v_{i}\right)}$

It can be noticed that the maximum feasible output is henceforth given by $f\left(x_{i} ; \beta\right) \exp \left(v_{i}\right)$ and take in consideration the effect random shocks specific to each producer. One of the specificities of this model comes from the fact that it allows the shocks to vary from one producer to another.

For our data analysis, a model of efficiency and technological diffusion similar to the one of Mastromarco (2005) is used. More specifically, we choose a model specification, which consists of a re-estimated Battese and Coelli (1992) efficiency model with non-neutral technological change. The model can also incorporate a quality-adjusted labour force with human capital included in the efficiency term. The production frontier function can be specified as:

$$
y_{i t}=f\left(x_{i t}, t, \beta\right)+\varepsilon_{i t}
$$

with

$$
\varepsilon_{i t}=v_{i t}-u_{i t}
$$

where $y_{i t}$ and $x_{i t}$ are, respectively, the output and a vector of inputs of country $i$ at the time t. $\beta$ is a vector of technological parameters to be estimated; Parameter $t$ is a time trend, and $f\left(x_{i t}, t, \beta\right)$ is the general form of the production function. $v_{i t} \sim\left(0, \sigma_{\varepsilon}^{2}\right), v_{i t}$, is assumed to be identically and independently distributed (iid) and uncorrelated with the inefficiency factor and the regressor.

Mastromarco adopted a translog (transcendental logarithm) production function. The function has the advantage to approximate an unknown production function (Christensen et al., 1973 cited by Mastromarco, 2005). The translog function with non-neutral technical change is made ad hoc with regional dummy variables replaced by selected countries dummy variables: Sel_Countries. 
The time dummy variables and other production factors variables are kept intact. The general form of the model to be estimated is presented as followed:

$$
\begin{aligned}
& \operatorname{Ln}\left(Y_{i t}\right)=\beta_{0}+\beta_{1} \ln \left(L_{i t}\right)+\beta_{2} \ln \left(K_{i t}\right)+\beta_{3} \ln \left(K_{i t}\right) \ln \left(L_{i t}\right)+ \\
& \beta_{4} 0,5 \ln \left(K_{i t}\right)^{2}+\beta_{5} 0,5 \ln \left(L_{i t}\right)^{2}+\beta_{6} S e l \_C o u n t r i e s+\beta_{7} t+\beta_{8} t^{2}+ \\
& +\beta_{9} \ln \left(K_{i t}\right) t+\beta_{10} \ln \left(L_{i t}\right) t-u_{i t}+v_{i t}
\end{aligned}
$$

Where $\ln \left(Y_{i t}\right)$ is the $\log$ of output $Y$ of the country $i$ at the time $t, \ln \left(K_{i t}\right)$, is the log of capital $K$, and $\ln \left(L_{i t}\right)$ is the $\log$ of labour L. The random term $v_{i t}$ is assumed iid normal, $v_{i t} \sim\left(0, \sigma_{v}^{2}\right)$ and also independent from the inefficiency factor $u_{i t}$. Sel_Countries (Selected Countries), country dummy variables are introduced to capture eventual specific effects common to the four selected countries and not shared by the other countries in our sample. This variable takes the value " 1 " for countries such as Benin, Ivory Coast, Ghana and Togo and takes the value "0" for the other remaining 8 countries.

The model is extended by including the time-variant form of inefficiency factor. Battese and Coelli (1992) present the inefficiency factor specified as the exponential specification of time-varying effects were the factor time $t$ effect is tested with an unknown parameter $\eta$. This inefficiency factor can be written as:

$$
u_{i t}=\{\exp [-\eta(t-T)]\} u_{i}
$$

$u_{i t}$ is assumed to be identically and independently distributed (iid) as a truncated-normal random variable, $u_{i t} \sim\left(\mu_{u}, \sigma_{u}^{2}\right)$. $\eta$ is an unknown scaler parameter to estimate, $t$ is the observation period of the countries, and $T$ is the last period.

Two different variants of the stochastic frontier model are estimated in this work. The general forms presented previously is estimated with some specifications across models. Thus, the Model 1 is the stochastic frontier model as presented above (Equation e1). It incorporates non-neutral technical change factors with time-variant estimated inefficiency factors. Model 2 differs from Model 1 by incorporating a quality-adjusted labour variable $L_{i t}{ }^{*}=L_{i t} * H C$. HC. HC is the Human Capital variable. The models are estimated for 12 countries located in West Africa namely, Benin, Burkina Faso, Ivory Coast, Ghana, Mali, Mauritania, Niger, Nigeria, Senegal, Sierra Leone, and Togo, over 20 years (1995-2014). But, for the study purpose, most of our analyses are focused on the countries of interest namely Benin, Ivory Coast, Ghana and Togo. The four remaining countries have been removed from the sample because of some missing data. The variables in this study are from two different sources. Y, GDP measured in 2011 US\$ constant price, is from WDI 2019. L, the number of workers in a country by year, is measured variable "emp" from Penn World Table 9.0 (PWT9.0). K, capital stock (rkna) measured at constant 2011 national prices (in million 2011 US\$) is from PWT 9.0. HC, from the Penn World Table (PWT 9.0) database, is the human capital index calculated based on years of schooling and returns to education. 


\section{Results and Analysis}

\subsection{Estimates and Model Specification}

Two different forms of our econometric model are estimated following Battese and Coelli's (1992) approach. Their approach allows for estimating simultaneously the stochastic frontier and a time-varying inefficiency equation. In this study, the estimated equations differ from each other by the type of factor labour they incorporate. Model 1 is the translog frontier estimation with the labour factor measured as the number of workers. Model 2 uses a quality augmented labour factor (number of workers multiplied by a human capital variable). The results of the econometric regressions are summarised in Table 1 . It contains the parameters estimated for the frontier model using the panel data of West African countries.

Table I: Maximum-Likelihood Estimates

\begin{tabular}{|c|c|c|}
\hline Variable & Model 1 & Model 2 \\
\hline Const & $\begin{array}{l}32.959 \\
(2.928)\end{array}$ & $\begin{array}{c}4.357 \\
(0.415)\end{array}$ \\
\hline $\ln \left(K_{i t}\right)$ & $\begin{array}{l}-4.575 \\
(-6.661)\end{array}$ & $\begin{array}{l}-2.101 \\
(-2.728)\end{array}$ \\
\hline $\ln \left(L_{i t}\right)$ & $\begin{array}{c}4.879 \\
(3.862)\end{array}$ & \\
\hline $\ln \left(L_{i t}^{*}\right)$ & & $\begin{array}{c}4.498 \\
(3.981)\end{array}$ \\
\hline $\ln \left(K_{i t}\right)^{2}$ & $\begin{array}{c}0.301 \\
(5.963)\end{array}$ & $\begin{array}{c}0.175 \\
(3.290)\end{array}$ \\
\hline $\ln \left(L_{i t}\right)^{2}$ & $\begin{array}{c}-0.082 \\
(-0.720)\end{array}$ & \\
\hline $\ln \left(L_{i t}^{*}\right)^{2}$ & & $\begin{array}{c}-0.100 \\
(-0.988)\end{array}$ \\
\hline $\ln \left(K_{i t}\right) \ln \left(L_{i t}\right)$ & $\begin{array}{l}-0.141 \\
(-2.445)\end{array}$ & \\
\hline $\ln \left(K_{i t}\right) \ln \left(L_{i t}^{*}\right)$ & & $\begin{array}{l}-0.103 \\
(-1.665)\end{array}$ \\
\hline Sel_Contries & $\begin{array}{l}-0.530 \\
(-2.782)\end{array}$ & $\begin{array}{l}-1.245 \\
(-4.269)\end{array}$ \\
\hline$t$ & $\begin{array}{c}0.044 \\
(0.914)\end{array}$ & $\begin{array}{l}-0.070 \\
(-1.488)\end{array}$ \\
\hline$t^{2}$ & $\begin{array}{c}-0.780 \mathrm{E}-03 \\
(-3.048)\end{array}$ & $\begin{array}{c}-0.001 \\
(-4.046)\end{array}$ \\
\hline $\ln \left(K_{i t}\right) t$ & $\begin{array}{l}-0.014 \\
(-6.930)\end{array}$ & $\begin{array}{l}-0.012 \\
(-6.979)\end{array}$ \\
\hline $\ln \left(L_{i t}\right) t$ & $\begin{array}{c}0.021 \\
(7.266)\end{array}$ & \\
\hline $\ln \left(L_{i t}^{*}\right) t$ & & $\begin{array}{c}0.024 \\
(7.041)\end{array}$ \\
\hline$N$ & 240 & 240 \\
\hline
\end{tabular}

Note: $\mathrm{K}=$ capital, $\mathrm{L}=$ Labour, $\mathrm{L}^{*}=$ quality augmented labour, $\mathrm{t}=$ Time, $\mathrm{N}=$ number of observations, Const=Constance, Sel_ Countries $=$ selected countries dummy and t-statistics in brackets. 
The variance parameters $\left(\gamma, \sigma^{2}, \mu, \eta, \mathrm{LL}\right.$ and LR) are presented in table 2 . The values reported in brackets are the t-statistics. These parameters are used to perform different inferences such as tests about the model's quality, about the model specification and inferences on the computed elasticities and return to scales.

Table 2: Variance Parameters

\begin{tabular}{ccc}
\hline & Model 1 & Model 2 \\
\hline $\boldsymbol{\sigma}^{\mathbf{2}}$ & 0.825 & 0.553 \\
& $(0.608)$ & $(1.071)$ \\
$\boldsymbol{\gamma}$ & 0.997 & 0.996 \\
$\boldsymbol{\mu}$ & $(176.436)$ & $(233.530)$ \\
& -0.777 & 0.473 \\
$\eta$ & $(-0.322)$ & $(0.722)$ \\
& 0.006 & 0.008 \\
$\boldsymbol{L}$ & $(3.199)$ & $(4.954)$ \\
$\boldsymbol{L} \boldsymbol{N}$ & 323.945 & 332.960 \\
$\boldsymbol{N}$ & 600.320 & 641.540 \\
\hline
\end{tabular}

Note: $\mathrm{LL}=\mathrm{Log}$-Likelihood, $\mathrm{LR}=$ Likelihood-Ratio test, $\mathrm{N}=$ number of observations and $\mathrm{t}$-statistics in brackets.

We perform statistical tests, to choose the best model. Table 3 shows the computed values for the selection criteria. These are the Akaike's Information Criterion (AIC) and Schwarz Criterion (SC). The AIC and the SC are calculated and the best model is chosen based on the minimal value of both two statistics. Following the AIC and SC criteria (see Table 3), Model 2 is chosen as the best one. It is the translog frontier estimation with time-varying efficiency and human capital augmented labour factor. However, for efficiency and elasticity analysis both of them have been used to go further in our comparison process.

Table 3: Model Selection Criteria

\begin{tabular}{ccccc}
\hline & LL $^{*}$ & K & AIC $^{1}$ & SC \\
\hline Model 1 & 323.945 & 11 & -2.84495 & -2.82783 \\
Model 2 & 332.960 & 11 & $\mathbf{- 2 . 9 2 6 9 1}$ & $\mathbf{- 2 . 9 0 9 7 8}$ \\
\hline
\end{tabular}

Note: ${ }^{*} \mathrm{LL}=\mathrm{Log}$-likelihood Function. $\mathrm{K}$ represents the total number of estimated parameters.

Some specification tests are performed on the estimated models. These consisted to verify if the translog function is the suitable function for our analysis. Specification tests are performed only on Model 2 as it has been chosen as the more suitable model of our study. The tests are a series of statistic inference of parameters to check whether alternative specifications are preferred to the one currently adopted. Four mains inference tests are performed:

$1 \quad A I C=-\frac{2}{T} L L+\frac{2 K}{T}, S C=-\frac{2}{T} L L+\frac{K \ln T}{T}$

With LL the estimated Log-likelihood function, $\mathrm{T}$ the number of observation and $\mathrm{K}$ the number of estimated parameters. (see Mastromarco, 2005, p.97-98) 
$H_{0}: \gamma=0$, the hypothesis of the absence of stochastic inefficiency effect in the model (Battese and Coelli's, 1995)

$H_{0}: \eta=0$, the null hypothesis of the absence of time-varying technical inefficiency.

$H_{0}: \beta_{3}=\beta_{4}=\beta_{5}=0$, the hypothesis of Cobb-Douglas specification as the appropriate model (instead of translog specification)

$H_{0}: \beta_{7}=\beta_{8}=\beta_{9}=\beta_{10}=0$, the hypothesis of the absence of technical change in the data.

$H_{0}: \beta_{9}=\beta_{10}=0$, the hypothesis of the absence of non-neutral technical progress in the appropriate model.

Table 4: Model Specification Tests Results

\begin{tabular}{|c|c|c|c|c|c|}
\hline Null Hypothesis & Log-Likelihood $^{(\mathrm{a})}$ & $\begin{array}{l}\text { General LR } \\
\text { Statistic }^{2}\end{array}$ & $\mathrm{DF}^{(\mathrm{b})}$ & Critical Value $^{3}$ & Decision \\
\hline$H_{0}: \gamma=0$ & 332.960 & 641.540 & 3 & 7.05 & $\mathrm{H}_{0}$ rejected \\
\hline$H_{0}: \eta=0$ & 312.529 & 40.861 & 1 & 3.800 & $\mathrm{H}_{0}$ rejected \\
\hline$H_{0}: \beta_{3}=\beta_{4}=\beta_{5}=0$ & 205.820 & 254.282 & 3 & 7.815 & $\mathrm{H}_{0}$ rejected \\
\hline$H_{0}: \beta_{7}=\beta_{8}=\beta_{9}=\beta_{10}=0$ & 141.183 & 383.553 & 4 & 9.488 & $\mathrm{H}_{0}$ rejected \\
\hline$H_{0}: \beta_{9}=\beta_{10}=0$ & 301.970 & 61.983 & 2 & 5.991 & $\mathrm{H}_{0}$ rejected \\
\hline
\end{tabular}

(a) Log-Likelihood value of estimated model under the null hypothesis assumption. ${ }^{(b)} \mathrm{DF}=$ Degree of Freedom, equal to the number of restrictions. Source: Authors' calculation.

The results of the tests on the Model 2 are reported in Table 4. All the null hypotheses are rejected. Thus, the stochastic frontier model with time-varying technical inefficiency is appropriate for our study. Also, the translog form, with the presence of non-neutral technical change is the appropriate econometric specification. More specifically, the translog function is preferred to the traditional Cobb-Douglas one. Also, we get no evidence for the rejection of the presence of nonneutral technical change effect in the model.

Some estimated parameters signs and sizes confirm these results about the model specification. First, it can be noticed that the values of the parameter $\gamma$ are positive and close to one (0.996 for Model 2, for example). As $\gamma=\frac{\sigma_{u}}{\sigma_{u}+\sigma_{v}}$ and the value obtained is close to 1, it confirms the righteousness of using the stochastic frontier model for our study. Also, the estimated value for

2 LR statistic test requires the estimation of both the model under the null hypothesis and model under the alternative hypothesis. The value of the statistic $L R$ is then given by $L R=-2\left[\log \left(L_{0}\right)-\log \left(L_{1}\right)\right]$. where $\log \left(\mathrm{L}_{0}\right)$ and $\log \left(\mathrm{L}_{1}\right)$ are the log-likelihood values respectively, under the null hypothesis and model assumed the rejection of the null hypothesis. The test is assumed asymptotically to follow a chi-square random variable distribution. However, in the case of $\gamma$ test, the statistic follows asymptotical a distribution given by a mixture of chi-square distribution:

$(1 / 2) \chi_{0}^{2}+(1 / 2) \chi_{1}^{2}$ (Coelli, 1995).

3 See chi-square table and table 1 of Kodde and Palm (1986) for LR test critical values 
$\eta$ is positive and indicate that countries' efficiencies tend to increase (inefficiency decrease) over time.

\subsection{Outputs' Elasticities and Returns to Scales}

Translog function offers a lot of possibilities and flexibilities for post-estimation analyses. However, in this type of function, estimated parameters in the stochastic production frontier are not directly interpretable. To get the effects of variation in production factors on the level of production, it is necessary to calculate the factors' elasticities. Also, this function allows verifying the homogeneity hypothesis by making statistical inference on the sum of computed elasticities. We then computed production elasticities to factors for Benin, Ivory Coast, Ghana, Togo and the panel as well. Both of the estimated equations are used. This procedure has the advantage to allow for comparing the change in elasticity values between Model 1 and Model 2 (the quality augmented labour factor model). These elasticities are computed with the partial derivation of the output function for capital $\left(e_{k}\right)$ and labour $\left(e_{l}\right)$ factors. Thus, we can get $e_{k}$ and $e_{l}$, using the means of capital, labour and time of the targeted sample and the estimated parameters with the following formula (Kumbhakar \& Wang, 2005):

$$
\begin{aligned}
& e_{k}=\frac{\partial \ln Y_{i t}}{\partial \ln K_{i t}}=\beta_{1}+\beta_{3} \ln \left(K_{i}\right)+\beta_{5} \ln \left(L_{i}\right)+\beta_{9} t \\
& e_{l}=\frac{\partial \ln Y_{i t}}{\partial \ln L_{i t}}=\beta_{2}+\beta_{4} \ln \left(L_{i}\right)+\beta_{5} \ln \left(K_{i}\right)+\beta_{10} t
\end{aligned}
$$

For the needed inference, standard errors of the above statistics have been calculated. So, we got to test the significance of the calculated marginal effects by computing their variance. They are obtained by applying the delta method. It mainly consists to calculate the variance as a linear combination of the estimates ${ }^{4}$ concerning each marginal effect. Table 5 displays the calculated statistics and their standard errors.

4 The variances can be obtained as followed (see Mastromarco, 2005, p.106):

$$
\begin{aligned}
& \operatorname{Var}\{\mathrm{ek}\}=\operatorname{Var}\left\{\beta_{1}+\beta_{3} \ln \left(K_{i}\right)+\beta_{5} \ln \left(L_{i}\right)+\beta_{9} t\right\}=Z_{k}^{\prime} \sum Z_{k} \\
& \operatorname{Var}\{\mathrm{el}\}=\operatorname{Var}\left\{\beta_{2}+\beta_{4} \ln \left(L_{i}\right)+\beta_{5} \ln \left(K_{i}\right)+\beta_{10} t\right\}=Z_{l}^{\prime} \sum Z_{l}
\end{aligned}
$$

With $\Sigma$, the estimated covariance matrix of maximum likelihood parameters of dimension (17x17). $Z^{\prime}$, a row vector with the same dimension with the matrix (here 17) which take the valour zero everywhere except when corresponding to the relevant $\beta_{4}$ for each marginal effect as follow:

- For capital factor K:

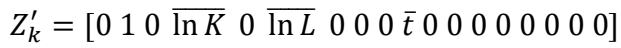

- For labour factor L:

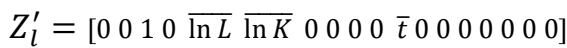


Table 5: Output Elasticities

\begin{tabular}{llcccc}
\hline & & \multicolumn{2}{c}{ Model 1 } & \multicolumn{2}{c}{ Model 2 } \\
\hline \multirow{3}{*}{ Benin } & Elasticity & Capital & Labour & Capital & Labour \\
& Standard Error & 0.031 & 0.057 & 0.041 & 0.098 \\
\multirow{2}{*}{ Ivory Coast } & Elasticity & $\mathbf{0 . 8 0 2}$ & 0.186 & $\mathbf{0 . 6 2 9}$ & 0.492 \\
& Standard Error & 0.049 & 0.056 & 0.064 & 0.107 \\
\multirow{2}{*}{ Ghana } & Elasticity & $\mathbf{0 . 7 9 0}$ & 0.147 & $\mathbf{0 . 5 7 5}$ & 0.411 \\
& Standard Error & 0.050 & 0.073 & 0.077 & 0.131 \\
\multirow{2}{*}{ Togo } & Elasticity & 0.338 & $\mathbf{0 . 5 6 0}$ & 0.364 & $\mathbf{0 . 7 9 1}$ \\
& Standard Error & 0.039 & 0.080 & 0.052 & 0.106 \\
& Elasticity & $\mathbf{0 . 5 5 4}$ & 0.398 & 0.500 & $\mathbf{0 . 6 7 4}$ \\
West Africa & Standard Error & 0.031 & 0.054 & 0.042 & 0.098 \\
& & & & & \\
\end{tabular}

Source: Authors' calculation using model estimates

As we can observe from Table 5, all the computed output elasticities are positive for both models. This is in line with our expectation. These elasticities express the change in output following a change in inputs (capital or/and labour). All the elasticities are significant at 5\% level. The values of the elasticities are between 0 and 1 , and it indicates that variation in any of the two inputs' quantity implies an under-proportional change in the output. The effects of simultaneous variations in inputs' quantities on output are discussed latter through the analysis of return to scales. To analyse the elasticities, we first consider differences between countries in Model 2 and then move to the Model 1. This second phase allows seeing the major differences between the computed elasticities with Model 1 and from Model 2.

In both the Model 2 and Model 1, output elasticities for inputs change across countries. At the panel level, we can see that in Model 2, output elasticity for labour factor is superior to the elasticity for capital. This higher value of labour elasticity obtained is similar to the results obtained by Mastromarco (2005), Piesse \& Thirtle (2000), and Koop et al. (2000b). Mastromarco (2005) explains this situation by one of the main characteristics of the production sector in developing countries. The economies of these countries are generally dominated by labourintensive production sectors such as agriculture. But the situation may also be understood by the role played by human capital in improving labour factor' quality. When looking at the Model 1 (with non-quality augmented labour), the result is reversed. Thus, capital elasticity in Model 1 is 0.554 (against 0.500 in Model 2), while the output elasticity for labour is 0.398 (against 0.674 
Model 2). This result, which highlight the role of human capital in the production technology, seems quite different from one country to another.

We can highlight some similarities between the situation observed in Model $2\left(e_{l}>e_{k}\right)$ for West Africa and those of Benin and Togo. Thus, we observe that in these countries, the output increase resulting from a $1 \%$ increase in labour factor is higher than the same change in the capital factor. This situation is, however, the opposite of the case of Ivory Coast and Ghana. In Ivory Coast, for example, according to the results from Model 2, a 1\% increase in labour leads to $0.492 \%$ increase in output, while the same $1 \%$ increase in capital factor lead to 0.629 increasing in the output. These relative scales observed, between labour and capital elasticities, in Ivory Coast are similar in Ghana. Thus, in Ghana output elasticity concerning labour is 0.411 against 0.575 for capital elasticity. The situation observed in Model $2\left(e_{l}>e_{k}\right)$ at the West African level is the same for Benin and Togo. We observe that in these countries, the output increase resulting from a $1 \%$ increase in labour factor is higher than the same change in the capital factor. The situations in Ghana and Ivory Coast could result from the fact that, contrary to Togo and Benin, these countries have higher stocks of capital and more developed industrial sectors. Ivory Coast and Ghana have latterly undergone structural transformations in their economies, having their industrial sector becoming the second contributor to their GDP at the expense of the agriculture sector (see Figure 1).

Figure I: Sector Added Value in Selected Countries (1990-2017)

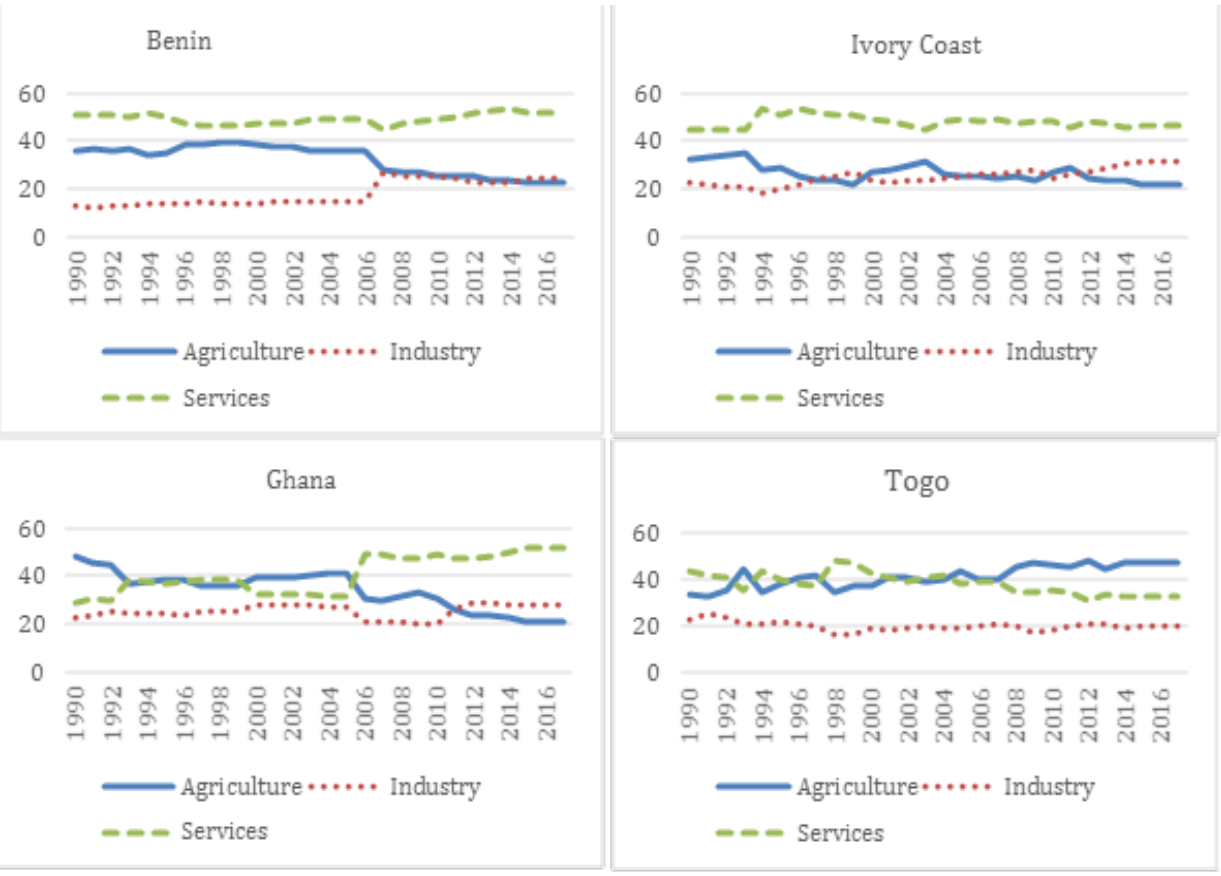

Source: Author's elaboration using African Development Bank Group (2019) 
Passing from Model 2 to Model 1 does not change that much the results for Ivory Coast and Ghana. Output elasticities concerning capital remain superior to the effects of change in labour on output. The labour factor's elasticity is much higher in Model 2 compared to Model 1 for both countries. However, in both of them, the observed increase in labour elasticities is followed by a decrease in the elasticities of the capital factor, from Model 1 to Model 2. Concerning Benin, labour elasticity (0.692) becomes higher, and it even passes the labour's contribution to output in Model 2. Concerning Togo's, its case completely differs compared to those of the rest of the countries. Its elasticity of labour remains higher than the contribution of capital, in both Model 1 and Model 2. However, the impact of labour on output increases when passing from Model 1 to Model 2, while the impact of capital remains approximately the same.

As for the elasticities, a difference can be seen in the computed returns to scale across models and countries. As expected, returns to scale concerning the Model 1 are lower than those gotten with the Model 2. This is normal with the hypothesis that human capital affects positively productivity leading to output increasing. We analyse the returns to scale computed with the Model 2's results (which is the best for analysis according to previous tests). The hypothesis of constant return to scale test is as follows:

$$
\begin{aligned}
& H_{0}: \sum \beta_{j}=1, \text { the constant return to scales } \\
& H_{1}: \sum \beta_{j} \neq 1, \text { decreasing } / \text { increasing } R S^{(*)}
\end{aligned}
$$

Note: $\left.{ }^{*}\right)$ RS=Return to Scales

In this table (Table 6), tests show that Benin and West Africa have constant return to scale while for Togo as for Ivory Coast, we get increasing returns to scales while Ghana has decreasing return to scales. But these results are just informative as they vary according to the point considered.

Table 6: Return to Scales $\left(\sum \boldsymbol{\beta}_{j}\right)$

\begin{tabular}{llcc}
\hline & & Model 1 & Model 2 \\
\hline Benin & Return to Scale & 0.948 & $\mathbf{1 . 1 7 4}$ \\
\multirow{3}{*}{ Ivory Coast } & Standard Error & 0.116 & 0.104 \\
& Return to Scale & 0.989 & 1.120 \\
Ghana & Standard Error & 0.098 & 0.094 \\
\multirow{2}{*}{ Togo } & Return to Scale & 0.937 & 0.986 \\
\multirow{3}{*}{ West Africa } & Standard Error & 0.094 & 0.105 \\
& Return to Scale & 0.899 & 1.155 \\
& Standard Error & 0.132 & 0.115 \\
& Return to Scale & 0.952 & $\mathbf{1 . 1 7 3}$ \\
\hline
\end{tabular}

Source: Authors' calculation 


\subsection{Human Capital and Efficiency Analysis}

Table 7 presents the median values of the efficiency's levels of the the selected countries' and the overall estimated median efficiency for West Africa. The estimated efficiencies from the model with labour measured by the number of workers (Model 1) and the model with the quality augmented labour factor (Model 2). It permits to go beyond comparative country analysis, and compare efficiency levels across models. Efficiency change across countries and even within the same country, it changes according to the model considered (see Table 7). Thus, while some countries experience increased efficiency following the inclusion of the quality augmented labour factor to the model, others countries have their efficiencies decreased. These changes seem to be normal. First, they highlight the importance of human capital in productivity gain in economies as stressed by endogenous growth models. Secondary, incorporating human capital in the labour factor changes the previously estimated production frontier of the region. Indeed, distances from countries' production levels to the new production frontier become either greater or shorter according to the effect of human capital on countries potentialities (through the effects on labour quality) concerning countries. By estimating two different models, we aim to go further in our analysis by examining the effect of human capital on the countries' efficiency levels.

Table 7: Selected Countries and Overall Estimated Efficiencies Mean and Median Values

\begin{tabular}{lcccc}
\hline & \multicolumn{2}{c}{ Model 1 } & \multicolumn{2}{c}{ Model 2 } \\
\hline Countries & Median value & Ranking & Median value & Ranking \\
Ivory Coast & 0.981 & 1 & 0.979 & 1 \\
Benin & 0.693 & 3 & 0.736 & 2 \\
Ghana & 0.901 & 2 & 0.706 & 3 \\
Togo & 0.592 & 4 & 0.610 & 4 \\
West Africa & 0.643 & & 0.491 & \\
\hline
\end{tabular}

Source: Authors' calculation

The estimated median efficiency value for the West African zone is 0.643 , in the first model. It is important to stress that the choice of the median values, instead of the means, does not particularly affect our analysis, since the observed median values are very close to the means for both models. In Model 2, we notice that the mean or median efficiency dropped to 0.491 (against 0,642 for Model 1). This change in the overall efficiency values, from Model 1 to Model 2, was expected. Indeed, the estimation concerned 20 years and, in both Model 1 and Model 2, the output and all other variables, excepted the labour factor, are held at their same annual values. Thus, any change in inefficiency value can be attributed to the changes in labour and its combination with capital factor. So, if we base our analysis on the assumption that human capital increases labour factor quality and contribute to improving productivity, the increase in inefficiency can be explained by the fact that, in both models, the level of output is kept constant while the level of labour (input) has increased. Unfortunately, our analysis does not permit to determine the potential change in production over time caused by the increase in labour quality in west African countries. Such analysis requires to get a perfect control sample which could allow measuring the potential output levels, with and without labour quality improvement. However, the reduction 
of efficiencies, observed from Model 1 and Model 2, could be explained by the misusing of the additional production potentiality given to countries by the effect of human capital on labour. Improvement in human capital can also help countries to adopt new technology and innovate in their production processes. Unfortunately, many of the studied countries failed to take advantage of it. Then, holding production constant, some countries which have improved their efficiency levels, while efficiency has decreased in other countries when the human capital factor is taking into account. But, after all, the most realistic model is Model 2. It helps to highlight the role of human capital in production. Also, based on econometric inferences, this model (Model 2) has been declared the most relevant for our study.

Among the four selected countries, Ivory Coast is the most efficient with a technical efficiency level of 0.979 (Model 2). It is followed by Benin and Ghana which have, respectively, 0.736 and 0.706 as their estimated median values of efficiency. Here, it is interesting to notice that except Ivory Coast, which has a production level very close to the West African frontier, the other three countries remain relatively more inefficient and have relatively lager improvement margins. Togo, for example, is the least efficient countries among all of them, with an efficiency level of 0.610. Concretely, we can say that, compared to other west African countries, Ivory Coast makes better use of its labour and its capital stock to achieve its level of production. Thus, an increase in the production factor results in more production. In the other side, countries such as Benin, Ghana and Togo are characterised by a relatively high level of inefficiency in their production process. The better labour-capital combination, further industrialisation, and innovation could have helped them to get a higher level of production with the level of factors held constant. It also passes through the improvement of the countries' education and health systems.

Finally, concerning the change in efficiency across models and countries, two opposite situations are observed. From Model 1 to Model 2, Benin and Togo's efficiency increase, while those of Ivory Coast and particularly Ghana decrease. It means that Ghana does not fully benefit from its remarkable improvement in human capital. This situation may also be explained by an eventual inadequacy between production in the education sector and the real need of the employment sector. Contrary to Ghana, Benin and Togo take advantage of the improvement in their human capital level to get closer to the production frontier. It means that human capital has contributed to productivity gain in these countries, and part of the growth in production is due to improvement in the education sector. But overall, the distance to the frontier remains high and more efforts need to be made.

\section{Conclusion}

West African zone is comprised of countries with modest economic performances. Our paper explores another way to approach growth accounting studies in West African countries. It aims at performing a comparative country analysis of production efficiency focusing on Benin, Ivory Coast, Ghana, and Togo. To achieve this goal, we use the SFA that allows measuring the 
contribution of factor to production, the returns to scales, and technical efficiencies. We also, briefly, analyse the effect of human capital on efficiency in the countries.

Our stochastic frontier analysis revealed that countries inefficiencies tend to reduce over time. Also, it reveals that Ivory Coast is the country with the highest level of efficiency among the 4 countries studied, and it remains, by far, one of the most efficient in West Africa. Ivory Coast is followed, respectively, by Benin, Ghana, and Togo when quality augmented labour factor is introduced into the model. The estimation without human capital (Model 1) shows that Ghana is more efficient than Benin. Regarding the contribution of factors to change in production, the labour factor contributes more to changes in production in Benin, Togo, and the West Africa Zone. In Ghana and Ivory Coast, capital elasticity remains higher than that of labour. However, it should be noted that, when the model without quality augmented human capital is considered, the output elasticities to capital remains superior to that of labour, in all the countries, excepted Togo.

This study contributes to the economic literature, by adding a plus to the previous growth studies carried out in the region. It fits into a regional context by considering countries belonging to the same region economic and customs union. This study, by performing this comparative analysis on countries similar, in terms of the structure of their economies, their institutions, their cultures, and geography, awakens the heterogeneity that characterises them. The analyses revealed also the importance of inefficiency in economic performances in West African countries. Apart from Ivory Coast, the level of inefficiency in the other three countries remains relatively high, and its reduction would contribute to increase the productivity of their economies, and lead to better economic performance in the sub-region. Better investments in human capital would have positive effects on growth in these countries. Also, improvement in education programs should take into account the adequacy problem between demand and supply on the job market. Policymakers should promote more investment in the economies to ensure better performances, in the long run. A reduction in public consumption expenditure could also have positive effects on growth in the long term.

This study focused more on the role of economic factors in determining countries' production level. Future studies could go further, by taking, for example, into consideration the role of institutions and the spatial aspects. Comparative analyses can be extended to more countries or regions. The use of models such as that of Battese \& Coelli (1995) would allow more interesting analysis by estimating the effect of independent variables on the level of technical inefficiency in economies.

\section{References}

Battese, G. E., \& Coelli, T. J. (1992). Frontier production functions, technical efficiency and panel data: with application to paddy farmers in India. Journal of productivity analysis, 3(1-2), 153-169.

Battese, G. E., \& Coelli, T. J. (1995). A model for technical inefficiency effects in a stochastic frontier production function for panel data. Empirical economics, 20(2), 325-332. 
Coelli, T. (1995). Estimators and hypothesis tests for a stochastic frontier function: A Monte Carlo analysis. Journal of productivity analysis, 6(3), 247-268.

Coelli, T. J., Rao, D. S. P., O’Donnell, C. J., \& Battese, G. E. (2005). An introduction to efficiency and productivity analysis. Springer Science \& Business Media.

Christensen, L. R., Jorgenson, D. W., \& Lau, L. J. (1973). Transcendental logarithmic production frontiers. The review of economics and statistics, 28-45.

Horrace, W. C., \& Schmidt, P. (1996). Confidence statements for efficiency estimates from stochastic frontier models. Journal of Productivity Analysis, 7(2-3), 257-282.

Karagiannis, G., \& Tzouvelekas, V. (2009). Parametric measurement of time-varying technical inefficiency: results from competing models. Agricultural Economics Review, 10(389-2016-23315), 50.

Kodde, D. A., \& Palm, F. C. (1986). Wald criteria for jointly testing equality and inequality restrictions. Econometrica: journal of the Econometric Society, 1243-1248.

Koop, G., Osiewalski, J., \& Steel, M. F. (1999). The components of output growth: A stochastic frontier analysis. Oxford Bulletin of Economics and Statistics, 61(4), 455-487.

Koop, G., Osiewalski, J., \& Steel, M. F. (2000 a). A stochastic frontier analysis of output level and growth in Poland and western economies. Economics of Planning, 33(3), 185-202.

Koop, G., Osiewalski, J., \& Steel, M. F. (2000 b). Modeling the sources of output growth in a panel of countries. Journal of Business \& Economic Statistics, 18(3), 284-299.

Kotsemir, M. (2013). Measuring national innovation systems efficiency-a review of DEA approach. Higher School of Economics Research Paper No. WP BRP, 16.

Kumbhakar, S. C., \& Wang, H. J. (2005). Estimation of growth convergence using a stochastic production frontier approach. Economics Letters, 88(3), 300-305.

Limam, Y. R. (2002). The components of output growth: A stochastic frontier analysis.

Mastromarco, C. (2005) Measuring efficiency in developing countries. Unpublished Ph.D. thesis, University of Glasgow.

Mastromarco, C. (2008). Stochastic frontier models. Italia: University of Salento. [online] Available: http:// www.camillamastromarco.it/CIDE/STFR.pdf (12/09/2018).

Piesse, J., \& Thirtle, C. (2000). A stochastic frontier approach to firm level efficiency, technological change, and productivity during the early transition in Hungary. Journal of comparative economics, 28(3), 473-501.

Schmidt, P., \& Sickles, R. C. (1984). Production frontiers and panel data. Journal of Business \& Economic Statistics, 2(4), 367-374.

Semanou, A. N. S., \& Uslu, K. (2019). Comparative Analysis of Growth Convergence in Selected West African Countries. Business and Economic Research, 9(3), 87-101. 